\title{
JUCER \\ The Implementation of Think Pair Share (TPS) Learning Model toward Student Achievement Learning in Material Acid and Base in Grade XI MA Sunan Pandanaran Academic Year 2018/2019
}

\author{
Nafisa Rahmaha, ${ }^{\mathrm{a},}$ Krisna Merdekawati ${ }^{\mathrm{a}}$, Artina Diniaty ${ }^{\mathrm{a}}$ \\ aUndergraduate Program in Chemistry Education, Faculty of Mathematics and Natural Sciences, \\ Universitas Islam Indonesia \\ *Corresponding author: 18614053@students.uii.ac.id
}

\begin{abstract}
The purpose of this study was to determine the significant difference in student achievement learning through the implementation of a think pair share (TPS) learning model and conventional learning model on acid-base material. This research is an experimental study using a quasi-experimental design, namely posttest only with nonequivalent group design. The study population was all students of class XI MA Sunan Pandanaran Yogyakarta academic year 2018/2019. The sample in this study was taken by purposive sampling technique as many as two classes. Data collection using the written test method with instruments in the form of multiple-choice questions to obtain data on learning achievement. Data analysis techniques in this study used the Mann Whitney Test. Based on the results of the study it can be concluded that there are significant differences in learning achievement between students who take part in the TPS learning model and students who take the conventional model learning on acid-base material.
\end{abstract}

Keywords: Think Pair Share (TPS), learning achievement, acid-base

\section{INTRODUCTION}

Chemistry is a branch of natural sciences which is studied at the high school (SMA) or Madrasah Aliyah (MA). This particular science discipline contains abstract concepts, but actually, this science is very closely related to daily life [1]. Chemistry in high school contains concepts that require a high level of understanding for students. One of the subject matters of chemistry in high school or MA is acid-base. Acid-base phenomena can be directly encountered in everyday life. The complex characteristics of acidbase material require a deep understanding of concepts. Based on the Regulation of the Minister of Education and Culture Number 24 of 2016, basic competence in acid-base material requires students to be able to explain the concepts of acids and bases as well as their strength and ionizing equilibrium in solution.

Basically, every human being needs learning to know everything that he doesn't know yet. Therefore, through the learning process, someone will know new things and be able to understand and understand something well. Learning is behavior when people learn, the response for the better. Learning is a complex activity. After learning people have skills, knowledge, attitudes, and values [2]. Everything that is obtained by students after the learning process takes place is called learning achievement. Learning achievement is the most important part of learning. It is stateed that learning achievement is a change achieved by someone after following the learning process. These changes include changes in overall behavior in attitudes, skills, and knowledge. Learning achievement referred to in this study is limited to the realm of knowledge.

Based on the results of observations made at MA Sunan Pandanaran, the teacher has organized student-centered learning, but student learning outcomes need to be improved. The average daily test scores of class XI MA Sunan Pandanaran students for the 2017/2018 school year on acid-base material have not fully met the minimum achievement score $(\geq 67)$. The average learning outcomes of students drawn from the two classes are 53,66. Understanding of students in the mastery of the concept of low impact on the low learning achievement of students and one of the factors that influence it is the model used in teaching. Therefore, the teacher's role is needed to change the learning model and the right 
approach to learn acid-base material. The teacher must be clever in choosing the strategy or approach to be used, but also choosing and using learning media that is suitable for the material to be delivered in the learning process.

One effort that can be used to overcome existing problems is to use cooperative learning strategies Think Pair Share (TPS) models. Basically, cooperative learning strategies are learning strategies that prioritize the existence of groups. Each student in the group has different levels of ability and if possible group members come from different races, cultures, ethnic groups and pay attention to gender equality [3]. The basic principle of cooperative learning is that students form small groups and teach each other to achieve common goals [4]. One of learning model that can be used is the Think Pair Share (TPS) model. The TPS learning model is a type of cooperative learning that is designed in the form of discussion to improve thinking skills, communication skills of students and encourage student participation in the classroom [5]. This model introduces the idea of "thinking time or waiting time" which is a strong factor in improving students' ability to respond to questions. TPS cooperative learning is relatively simpler because it does not take a long time to arrange seats or classify students. This learning trains students to dare to think and respect the opinions of friends [6]. Based on the description above, through the application of the TPS type learning model in class XI MA Sunan Pandanaran Yogyakarta it is expected that there will be a significant difference in terms of learning achievement in the domain of students' better knowledge.

\section{METHODS}

This experimental research was carried out using the quasi-experimental design namely the post-test only with nonequivalent groups design. The design of this research involves the learning outcomes of the domain of knowledge from the two classes being compared, namely the experimental class and the control class. The TPS learning model is applied in the experimental class and the conventional learning model is applied in the control class.

TABLE 1. Experimental Research Design

\begin{tabular}{ccc}
\hline Class & Treatment & Final state \\
\hline Experiment & $\mathrm{X}$ & $\mathrm{Y}$ \\
Control & - & $\mathrm{Y}$ \\
\hline
\end{tabular}

$\mathrm{X}$ : Learning chemistry using the TPS model

$Y$ : The experimental class and the control class were given a posttest

The study was conducted in class XI MA Sunan Pandanaran, Sardonoharjo, Ngaglik District, Sleman Regency, Special Region of Yogyakarta in February 2019 - April 2019. Retrieval of research data was carried out through five meetings for each class in learning activities and data collection and once. a meeting for daily tests in each class. The population in this study were all students of class XI MA Sunan Pandanaran Academic Year 2018/2019. The sample used in this study were students in class XI MIA A and class XI MIA B MA Sunan Pandanaran in the Academic Year 2018/2019.

Sampling in this study used a purposive sampling technique, which is a sampling technique based on research objectives [7]. The independent variable in this study is the TPS type of cooperative learning model in the experimental class while the dependent variable in this study is the learning achievement. Chemistry learning achievement of students is the score obtained by students in working on multiplechoice questions. Data collection techniques in this study were conducted using the written test method in the form of multiple-choice questions to obtain data in the form of learning achievement in the realm of knowledge. The instrument used in this study consisted of research implementation instruments and data collection instruments. Research implementation instruments include the syllabus, learning plan (RPP). Data collection instruments include learning achievement instruments in the form of multiple-choice questions, which are complemented by a grid of learning achievement test instruments.

Data analysis techniques in this study use a homogeneity test to find out samples from homogeneous or inhomogeneous populations. The homogeneity test is done by looking at the population homogeneity. The researcher uses Levene's test to see whether the experimental and control class data are homogeneous or not. Both classes are declared homogeneous if sig $>0.05$. Furthermore, this study uses a normality test. This normality test is used to investigate the data in this study whether normal or not. The 
normality test in this study uses the Shapiro-Wilk Criteria. The research data was stated to be normally distributed if sig> 0.05 .

The final stage of this hypothesis test is used to determine the effect of applying the type of TPS cooperative learning model to the learning achievement of the students' knowledge domain. This hypothesis test was conducted to see a significant difference in the learning achievement of the students' knowledge domain through the application of the TPS learning model and the conventional learning model on the acid-base material of class XI MA Sunan Pandanaran in the 2018/2019 school year.

The hypothesis test decision in this study uses the Independent Sample T-Test parametric analysis if the data is normally distributed and homogeneous. If the parametric analysis prerequisite test is not met, then the hypothesis test is performed using a nonparametric analysis Mann Whitney Test. The hypotheses in this study are:

$\mathrm{Ho}=$ There is no significant difference in the learning achievement of the students' knowledge domain through the application of TPS learning models and conventional learning models on acid-base material

$\mathrm{Ha}=$ There is a significant difference in the learning achievement of the students' knowledge domain through the application of TPS learning models and conventional learning models on acid-base material

The hypothesis test decision in this study is if the significance value $<0.05$, then Ho is rejected. In testing, the researchers used SPPS 20.0 software.

\section{RESULTS AND DISCUSSION}

Research that has been carried out at MA Sunan Pandanaran is to find out whether or not there are differences between the application of the TPS learning model with conventional learning models on the learning achievements of the knowledge domain. The study was conducted in class XI-A as an experimental class and class XI B as a control class. The instrument used in this study was a multiple choice question that had previously been validated by an expert or validator consisting of 1 UII chemistry education lecturer namely Ms. Artina Diniaty, S. Pd. Si., M.Pd. and 1 chemistry teacher at MA Sunan Pandanaran, namely Mrs. Lilik Nuroiniyah, S.Pd. The validated research instrument was then trialled to students of class XII MIA-B MA Sunan Pandanaran. Based on the results of the trial obtained 27 valid questions out of 50 questions. Data on learning achievement results can be seen in Table 2.

TABLE 2. Student Learning Achievement Results

\begin{tabular}{cccc}
\hline Class & Lowest Value & Highest Value & Average \\
\hline Experiment & 59,26 & 96,3 & 77,23 \\
Control & 37,04 & 81,48 & 64,39 \\
\hline
\end{tabular}

Testing the data analysis requirements in this study include the normality test and homogeneity test. The results of the data analysis test in the experimental class and the control class are presented in Table 3.

TABLE 3. Prerequisite Test Data for Learning Achievement Hypotheses

\begin{tabular}{|c|c|c|c|c|c|}
\hline \multirow[b]{2}{*}{ Class } & \multicolumn{2}{|c|}{ Normality } & \multicolumn{2}{|c|}{ Homogeneity } & \multirow[b]{2}{*}{ Conclusion } \\
\hline & Sig. & $\begin{array}{l}\text { Informati } \\
\text { on }\end{array}$ & Sig. & $\begin{array}{l}\text { Informati } \\
\text { on }\end{array}$ & \\
\hline $\begin{array}{l}\text { Experime } \\
\text { nt }\end{array}$ & $\begin{array}{l}0,33 \\
7\end{array}$ & Normal & 0,46 & Homogen & Nonparamet \\
\hline Control & $\begin{array}{l}0,00 \\
4\end{array}$ & Abnormal & 8 & попйgen & ric Test \\
\hline
\end{tabular}

Normality testing is done aims to determine whether the data obtained are normally distributed or not. If the sig value is $>0.05$ so the data is normally distributed. Testing is done using the Shapiro-Wilk test. The results of the normality test are presented in Table 4 . 
TABLE 4. Normality Test Results

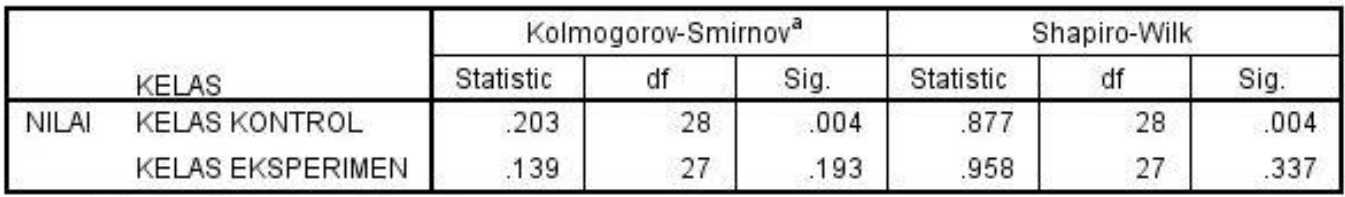

Based on Table 4, it can be seen that the data on the learning achievement of the students' knowledge in the class using the cooperative type TPS model and the class using the conventional learning model are both homogeneous. However, the normality test data in the experimental class is normally distributed while the data in the control class is not normally distributed. The graph showing the distribution of data in the experimental class and the control class is as follows:

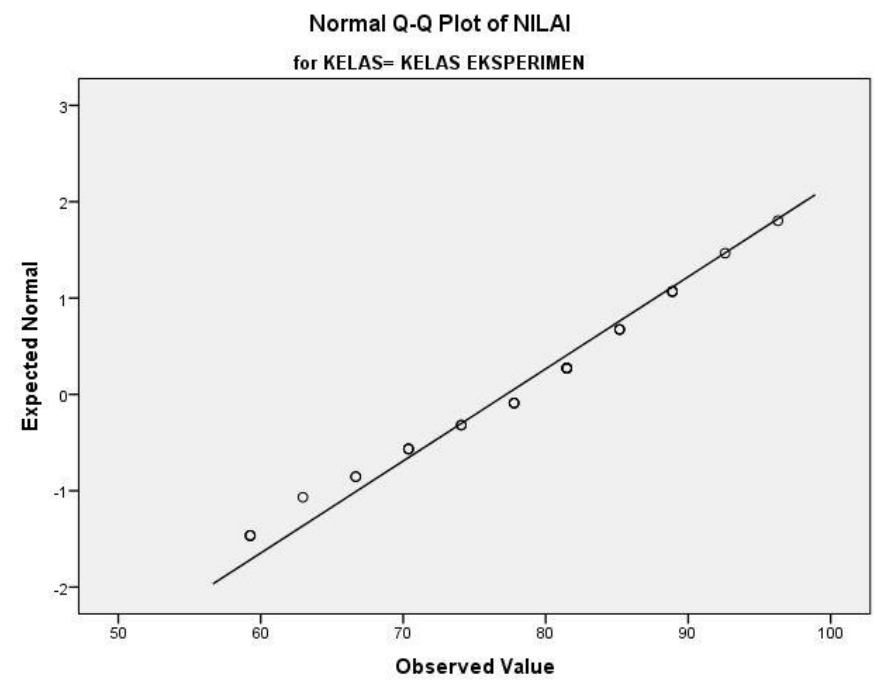

FIGURE 1. Data Distribution in Experimental Classes

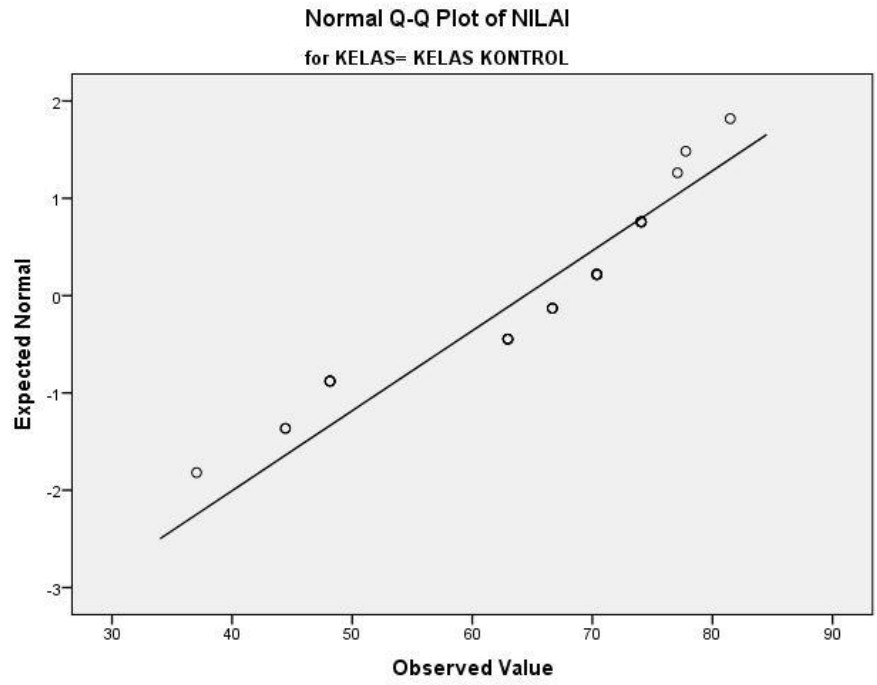

FIGURE 2. Data Distribution in the Control Class

Based on the normality test chart, for the normally distributed experimental class, it can be seen from the linearly formed graph. The next step after the data is normally distributed is to do a homogeneity test to prove the variance of both homogeneous classes or not. Both classes are declared homogeneous when 
sig> 0.05. Based on Table 5 it can be seen that the variance of both classes is homogeneous with $=5 \%$. In Levene's Test, the significant value is $0.468>0.05$ which means the data is homogeneous.

TABLE 5. Homogeneity Test Results

\begin{tabular}{|r|r|r|c|}
\hline $\begin{array}{l}\text { Levene } \\
\text { Statistic }\end{array}$ & df1 & df2 & Sig. \\
\hline .533 & 1 & 53 & .468 \\
\hline
\end{tabular}

The hypothesis test used in this study is the nonparametric statistical test, namely Mann Whitney, because based on the normality test in the control class, a sig value of 0.004 is obtained which indicates a significance value $<0.05$ so that the data are not normally distributed. The testing of this hypothesis aims to find out significant differences in the learning domain of knowledge. Hypothesis test results of the learning domain of knowledge tested with the Mann Whitney test obtained sig. 0,000. The results of statistical tests of students' learning achievement data are presented in Table 6.

TABLE 6. Results of Statistical Tests on Data Achievement in th

\begin{tabular}{|l|r|}
\hline & \multicolumn{1}{|c|}{ NILAI } \\
\hline Mann-Whitney U & 166.500 \\
Wilcoxon W & 572.500 \\
Z & -3.579 \\
Asymp. Sig. (2-tailed) & .000 \\
\hline
\end{tabular}

Based on the results of the hypothesis test of learning achievement using Mann Whitney nonparametric test, obtained a significance value of 0,000 , which means a significance value $<0.05$ so that Ho is rejected. This shows that there are significant differences in learning achievement between students who are treated with the TPS learning model and students who are treated with conventional learning models. Based on the results obtained indicate that the application of learning models can have an impact on students' chemistry learning achievement. The test results prove the research hypothesis that there are significant differences in the learning achievement of the students' knowledge domain through the application of the TPS learning model and the conventional learning model on the acid-base material of class XI MA Sunan Pandanaran in the 2018/2019 school year.

The results of this study are in line with the research of Jannah et al. (2013) which proves that TPS learning that is accompanied by a pocketbook on petroleum material for Gondangrejo High School students in the 2012/2013 academic year can improve student achievement in the aspect of knowledge [8]. In addition, the results of this study are in line with the results of Rewa, et al. (2014) that the learning outcomes of students with TPS cooperative learning can be improved compared to conventional learning models on atomic structure material [9].

Based on research that has been done, there are differences in the average learning outcomes of students who are given conventional learning model learning with students who are given TPS learning models. The problem when applying conventional learning models is the low learning achievement of the students 'knowledge domain so that the average daily test of students does not meet the KKM score $\geq 67$. The average learning outcomes of the students' knowledge in the control class given conventional learning are 64.39. While the average learning outcomes of the students' knowledge in the experimental class who were given TPS learning was 77.23 .

The TPS learning model applied during the learning process in the experimental class begins with the individual think stage. This individual thinking stage requires students to be more diligent in learning so as to be able to solve the problems given by the teacher. At this stage, students look actively working on the problems independently. In addition, students are encouraged to master acid-base material because of the moral responsibility towards the group, because individual values are taken from the average group value. The next stage is students are asked to discuss the results of their thoughts in pairs (pairs). Students exchange their respective arguments and discuss with each other so that the same thought results are 
obtained. During the discussion, activities can make students trained to solve problems and understand the answers to the questions given. This looks different when learning is conventionally applied, the process of exchanging opinions is minimal, resulting in students being less active because opportunities for discussion are lacking. In addition, conventional learning places the teacher's position as the main information center that plays a dominant role and students tend to be passive in the learning process. The next stage is sharing, the results of discussion of students who are paired are shared with all students in front of the class, so they are able to explain the results of the answers that have been discussed.

The learning process looks significantly different in the control class that uses conventional learning. The learning that takes place is learning only by listening to the explanation from the teacher and doing the exercises given by the teacher. During the discussion activities, students were still reluctant to discuss with other friends. Some students still work individually without wanting to discuss in solving problems. In the discussion activity, only a few people seemed enthusiastic to ask questions or opinions. Students are still shy and lack courage in asking questions relating to the acid-base material discussed.

The application of the TPS learning model in this study shows that the application of the TPS learning model has a better impact in terms of learning achievement in the realm of knowledge because by giving students time to think about the issues of acid-base material provided, sitting in pairs by forming heterogeneous groups, mutual discuss and express opinions and share with each other the results of the discussion. In addition to obtaining maximum results in the learning process, this TPS learning model is applied to encourage students to build their own knowledge by thinking about a given problem so that the student is able to know the problem of knowledge that will be given.

\section{CONCLUSION}

Based on the analysis of research data and discussion that has been described, it can be concluded that there are significant differences in the learning achievement of the students' knowledge domain through the application of the TPS learning model and the conventional learning model on the acid-base material of class XI MA Sunan Pandanaran in the 2018/2019 school year.

\section{REFERENCES}

1. Faizah, S. S. Miswadi, S. Haryani, Jurnal Pendidikan IPA Indonesia 2 (2) (2013).

2. Dimyati, Mudjiono, Belajar dan Pembelajaran. (Rineka Cipta, Jakarta, 2002).

3. Daryanto, R. Muljo, Model Pembelajaran Inovatif. (Gava Media, Yogyakarta, 2012).

4. W. Made, Jakarta: Bumi Aksara, 53 (2009).

5. N. A. N. Azlina, International Journal of Computer Science Issues (IJCSI) 7 (5), 18 (2010).

6. A. Shoimin, Enam Puluh Delapan Model Pembelajaran Inovativ dalam Kurikulum 2013. (ArRuzz Media, Yogyakarta, 2014).

7. Sugiyono, Metode penelitian pendidikan:(pendekatan kuantitatif, kualitatif dan R \& D). (Alfabeta, 2008).

8. R. Jannah, A. N. C. Saputro and S. Yamtinah, Jurnal Pendidikan Kimia 2 (4), 19-23 (2013).

9. Z. S. Rewa, R. Ratman and I. Said, Jurnal Akademika Kimia 3 (3), 150-157. 